\title{
Effect of cadmium on anion exchange capability through Band 3 protein in human erythrocytes
}

\author{
Rossana Morabito, ${ }^{1}$ Alessia Remigante, ${ }^{1}$ Benedetta Arcuri, ${ }^{1}$ Angela Marino, ${ }^{1}$ Marco Giammanco, ${ }^{2}$ \\ Giuseppina La Spada, ${ }^{1}$ Angela Marino ${ }^{1}$ \\ ${ }^{1}$ Department of Chemical, Biological, Pharmaceutical and Environmental Sciences, University of Messina, Messina; \\ ${ }^{2}$ Department of Biomedicine and Clinical Neurosciences, University of Palermo, Palermo, Italy
}

\begin{abstract}
The efficiency of transport through Band 3 protein, mediating $\mathrm{HCO}_{3}{ }^{-} / \mathrm{Cl}^{-}$exchange across erythrocytes membrane, is reduced by oxidative stress. The aim of the present study was to verify whether Band 3 protein transport efficiency is compromised by treatment with Cadmium $\left(\mathrm{Cd}^{2+}\right)$, an extremely toxic heavy metal known to interfere with antioxidant enzymes, energy metabolism, gene expression and cell membranes. To this end, the rate constant for $\mathrm{SO}_{4}=$ uptake through Band 3 protein (accounting for velocity of anion exchange) was measured along with membrane-SH groups, Malonyldialdehyde (MDA) and Band 3 protein expression levels in $\mathrm{Cd}^{2+}$-treated human erythrocytes $(300 \mu \mathrm{M}, 1 \mathrm{mM})$. Our results show that $\mathrm{Cd}^{2+}$ reduced the rate constant for $\mathrm{SO}_{4}{ }^{=}$uptake, with a significant increase in MDA levels at both concentrations and with a reduction in $-\mathrm{SH}$ groups observed after $1 \mathrm{mM} \mathrm{Cd}^{2+}$ treatment, whereas Band 3 protein expression levels were unchanged in both
\end{abstract}

Correspondence: Angela Marino, Department of Chemical, Biological, Pharmaceutical and Environmental Sciences, University of Messina, Viale F. Stagno D’Alcontres 31, 98166 Messina, Italy.

E-mail:marinoa@unime.it

Key words: Cadmium; Oxidative stress; $\mathrm{SO}_{4}=$ uptake; Band 3 protein; Erythrocyte.

Contributions: RM, AR, AM1, BA, performing experiments, data collecting and analysis; MG and GLS, manuscript reviewing; AM2, experimental design, manuscript writing and reviewing.

Conflict of interest: the authors declare no potential conflict of interest.

Funding: none.

Received for publication: 27 November 2017.

Revision received: 7 February 2018

Accepted for publication: 13 February 2018.

CCopyright R. Morabito et al., 2018

Licensee PAGEPress, Italy

Journal of Biological Research 2018; $91: 7203$

doi:10.4081/jbr.2018.7203

This article is distributed under the terms of the Creative Commons Attribution Noncommercial License (by-nc 4.0) which permits any noncommercial use, distribution, and reproduction in any medium, provided the original author(s) and source are credited. conditions. In conclusion: i) $\mathrm{Cd}^{2+}$ reduces Band 3 protein transport efficiency via different mechanisms depending on metal concentration and with unchanged expression levels; ii) the assessment of Band 3 protein anion exchange capability is a good tool to assay the impact of heavy metals on cell homeostasis and, possibly, useful for diagnosis and monitoring of development of $\mathrm{Cd}^{2+}$ toxicity-related pathologies.

\section{Introduction}

Band 3 protein is the most abundant integral protein of erythrocyte membrane ${ }^{1}$ and its crystal structure was defined in $2015 .^{2}$ Band 3 protein has been extensively studied in wild-type human mature erythrocytes, during their maturation, and in connection with possible defects of membrane skeleton. ${ }^{3,4}$ It is critically involved in maintenance of erythrocytes deformability and ion balance essential to gas exchange efficiency, making thus the evaluation of anion exchange capability $\left(\mathrm{Cl}^{-} / \mathrm{HCO}_{3}{ }^{-}\right)$useful to check erythrocytes homeostasis in health and disease. ${ }^{5,6}$ Band 3 protein functions are mediated by two domains, a membrane domain for anion exchange and a cytoplasmic domain which mainly contributes to the protein-protein interactions, by coupling the lipid bilayer to the underlying cytoskeleton, through cysteine SH groups. ${ }^{7}$ Human erythrocytes, being constantly exposed to oxidative stress, have been already used as a model to study possible alterations due to oxidants like $\mathrm{H}_{2} \mathrm{O}_{2}$ or $N$-Ethylmaleimide (NEM) at level of methemoglobin production, lipid peroxidation, membrane $-\mathrm{SH}$ groups oxidation, efficiency of anion exchange capability through Band 3 protein and phosphorylation of Band 3 protein Tyrosine residues. ${ }^{8,9}$

Among oxidants, Cadmium $\left(\mathrm{Cd}^{2+}\right)$, a widely distributed and extremely toxic heavy metal, has been proven to alter antioxidant enzymes, energy metabolism, membrane arrangement, gene expression and apoptosis, though the exact mechanism of its toxicity is still not completely understood. ${ }^{10-13}$ It enters blood stream, binds to the erythrocyte membrane and stimulates reactive oxygen species (ROS) formation, ${ }^{10}$ affecting the antioxidant system and increasing lipid peroxidation. ${ }^{10,13}$ In addition, $\mathrm{Cd}^{2+}$ has been shown to alter lipid bilayer molecular structure, thus modifying the biophysical properties of cell membrane such as fluidity, which in turn affects signals transduction, channel functions and protein activity. ${ }^{14}$

Cadmium is found in many natural foods, particularly in grains and seaweed among vegetables, and, with regard to animals, in fishes and shellfishes. As pointed out by Satarug et al. ${ }^{15}$ human exposure to $\mathrm{Cd}^{2+}$ is mostly through foods $(90 \%)$ and has been 
linked to increased risk of bone fracture, cancer, kidney dysfunction, and hypertension. ${ }^{15}$ However, cigarette smoke should be not excluded as source of the body cadmium $\mathrm{Cd}^{2+}$ burden, being tobacco plant a cadmium bioaccumulator. ${ }^{16}$ In any case, once absorbed into blood circulation, $\mathrm{Cd}^{2+}$ may exert its toxic effect by damaging cell membranes ${ }^{17}$ at concentrations 10 folds lower than those currently used in in vitro assays. ${ }^{14}$ Despite this discrepancy, in vitro experiments have been conducted in order to rapidly evaluate $\mathrm{Cd}^{2+}$ effects at cellular level after brief exposure to the metal. ${ }^{14,18}$ In particular, Suwalski et al. ${ }^{14}$ point out that $1 \mathrm{mM} \mathrm{Cd}^{2+}$, from one hand is effective in altering erythrocytes membrane, and, from the other hand, similarly to other in vitro studies, ${ }^{17,19}$ is at least 10 -folds higher than its toxic concentration in blood. ${ }^{20}$

On these premises, the present investigation aims to verify whether and how Band 3 protein transport efficiency in human erythrocytes is affected by a transient exposure to $\mathrm{Cd}^{2+}$ and whether monitoring anion exchange capability may be considered as an additional tool for diagnosis and monitoring of development of pathologies related to cadmium $\mathrm{Cd}^{2+}$ toxicity.

To this end, erythrocytes have been exposed for $1 \mathrm{~h}$ at $\mathrm{Cd}^{2+}(300$ $\mu \mathrm{M}$ and $1 \mathrm{mM}$ ), in order to produce oxidative damage, according to other in vitro investigations, ${ }^{14}$ assaying the effects of $\mathrm{Cd}^{2+}$ within this range of concentrations.

$\mathrm{Cd}^{2+}$-induced oxidative damage has been assessed by measuring levels of both membrane - $\mathrm{SH}$ groups, mostly deriving from Band 3 protein, ${ }^{21}$ and Malonyldialdehyde (MDA) - the end product of lipid peroxidation - while the efficiency of anion transport through Band 3 protein has been monitored by determining the rate constant for $\mathrm{SO}_{4}=$ uptake, which accounts for exchange velocity and is more easily estimated than $\mathrm{Cl}^{-}$or $\mathrm{HCO}_{3}{ }^{-}$uptake. ${ }^{22-24}$ Expression levels of Band 3 protein in $\mathrm{Cd}^{2+}$-treated erythrocytes have been also determined.

\section{Materials and Methods}

\section{Erythrocytes preparation}

Human blood was obtained from healthy volunteers upon informed consent. Blood was collected in heparinized tubes, washed in an isotonic solution (composition in mM: $145 \mathrm{NaCl}, 20 \mathrm{HEPES}$ (4-(2-hydroxyethyl)-1 piperazineethanesulfonic acid), $\mathrm{pH}$ 7.4, osmotic pressure $300 \mathrm{mOsm}$ ) and centrifuged thrice (ThermoScientific, $1000 \mathrm{~g}, 5 \mathrm{~min}$ ) to remove plasma and buffy coat.

\section{$\mathrm{SO}_{4}=$ uptake measurement}

Human erythrocytes were suspended to $3 \%$ hematocrit in $35 \mathrm{~mL}$ isotonic $\mathrm{SO}_{4}{ }^{=}$-containing medium defined as $\mathrm{SO}_{4}{ }^{=}$medium (composition in mM: $118 \mathrm{Na}_{2} \mathrm{SO}_{4}, 20$ HEPES, 15 glucose, $\mathrm{pH} 7.4$, osmotic pressure $300 \mathrm{mOsm})$. At specified time intervals (5-10-1530-45-60-90-120 min), $5 \mathrm{~mL}$ samples of erythrocytes suspension were treated with $10 \mu \mathrm{M} 4,4$ '-diisothiocyanatostilbene-2, 2'-disulphonic acid (DIDS), a specific and irreversible blocker of Band 3 protein ${ }^{25}$ and kept on ice. After the last sample withdrawal, erythrocytes were washed thrice by centrifugation in cold isotonic solution (ThermoScientific, $4^{\circ} \mathrm{C}, 1000 \mathrm{~g}, 5 \mathrm{~min}$ ) to remove $\mathrm{SO}_{4}=$ from the external medium and then hemolysed by $1 \mathrm{~mL}$ distilled water, while proteins were hydrolysed with $4 \% \mathrm{v} / \mathrm{v}$ perchloric acid. Centrifugation $\left(4^{\circ} \mathrm{C}, 2400 \mathrm{~g}, 10 \mathrm{~min}\right)$ allowed to obtain $\mathrm{SO}_{4}{ }^{=}$-containing supernatant used for turbidimetric method. $\mathrm{SO}_{4}{ }^{=}$was precipitated by adding 500 $\mu \mathrm{L}$ supernatant from each sample to $1 \mathrm{~mL}$ glycerol and distilled water solution (1:1), $1 \mathrm{~mL} 4 \mathrm{M} \mathrm{NaCl}$ plus hydrochloric acid (HCl 37\%) solution (12:1) and $500 \mu \mathrm{L} 1.24 \mathrm{M} \mathrm{BaCl}_{2} \cdot 2 \mathrm{H}_{2} \mathrm{O}$. Total amount of $\mathrm{SO}_{4}=$ internalized by erythrocytes at fixed times was spectrophotometrically quantified (425 nm wavelength, Beckman DU 640) and the absorption converted to $\mathrm{mM}$ of $\mathrm{SO}_{4}=$ using a calibrated standard curve previously obtained by precipitating known $\mathrm{SO}_{4}{ }^{=}$amounts. The rate constant, measured in $\mathrm{min}^{-1}$, was then calculated by the following equation: $\mathrm{C}_{t}$ $=\mathrm{C}_{\infty}\left(1^{-\mathrm{e}-\mathrm{rt}}\right)+\mathrm{C}_{0}$, where $\mathrm{C}_{\mathrm{t}}, \mathrm{C}_{\infty}$ and $\mathrm{C}_{0}$ represent the intracellular $\mathrm{SO}_{4}=$ total amount measured at time t, 0 and $\infty$ respectively; $e$ indicates Neper number (2.7182818); $r$ is the rate constant of the transport process and $t$ is time fixed for each sample withdrawal (5-10-15-3045-60-90-120 min). The reciprocal of rate constant for $\mathrm{SO}_{4}=$ uptake (min) represents the time needed to reach $63 \%$ of total $\mathrm{SO}_{4}=$ intracellular total amount. ${ }^{23}$

With regard to $\mathrm{Cd}^{2+}$ treatment, erythrocytes, after washing, were diluted to $3 \%$ hematocrit and treated with $\mathrm{CdCl}_{2}$ doses comprised between $50 \mu \mathrm{M}$ and $1 \mathrm{mM}$ for one hour at $37^{\circ} \mathrm{C}$ in isotonic solution. During incubation, light microscope observations were performed to exclude possible $\mathrm{Cd}^{2+}$-dependent hemolysis. After incubation, samples were centrifuged (1000 g, $5 \mathrm{~min}$ ) to remove the supernatant, re-suspended to $3 \%$ hematocrit in $\mathrm{SO}_{4}=$ medium containing $\mathrm{Cd}^{2+}$ and $\mathrm{SO}_{4}=$ uptake measured as described for control conditions.

Based on $\mathrm{SO}_{4}=$ uptake measurement, two $\mathrm{Cd}^{2+}$ doses $(300 \mu \mathrm{M}$ and $1 \mathrm{mM}$ ) have been chosen to complete the experimental design.

\section{Membrane-SH groups determination}

Membrane - $\mathrm{SH}$ groups estimation was performed on erythrocytes (untreated or treated with $\mathrm{Cd}^{2+}$ ) according to Roy and co-workers. ${ }^{21}$ In details, erythrocytes, after washing, were treated with $300 \mu \mathrm{M}$ and $1 \mathrm{mM} \mathrm{Cd}^{2+}$ to $3 \%$ hematocrit for one hour at $37^{\circ} \mathrm{C}$. After the incubation, they were centrifuged (ThermoScientific, $1000 \mathrm{~g}, 5 \mathrm{~min}$ ), concentrated to $10 \%$ hematocrit and lysed by cold hypotonic buffer $\left(2.5 \mathrm{mM} \mathrm{NaH}_{2} \mathrm{PO}_{4}, 5 \mathrm{mM}\right.$ HEPES). After $10 \mathrm{~min}$ stirring at $0^{\circ} \mathrm{C}$, hemoglobin and intracellular content were discarded by repeated centrifugations (Eppendorf microfuge, $4^{\circ} \mathrm{C}, 18000 \mathrm{~g}, 20 \mathrm{~min}$ ). The process was repeated with the same hypotonic buffer to discard hemoglobin. One volume of membranes (from both treated and untreated erythrocytes) was then incubated with nine volumes of $0.1 \mathrm{M} \mathrm{NaOH}$ for $30 \mathrm{~min}$ at $0^{\circ} \mathrm{C}$ plus $200 \mu \mathrm{M}$ dithiothreitol and $20 \mu \mathrm{g} / \mathrm{ml}$ Phenylmethylsulfonil fluoride (PMSF). After incubation, samples were centrifuged $\left(4^{\circ} \mathrm{C}, 18000\right.$ $\mathrm{g}, 45 \mathrm{~min}$ ). The pellet, containing Band 3 protein, was washed thrice with $5 \mathrm{mM}$ sodium phosphate $(\mathrm{pH} \mathrm{8.0)}$ and used for $-\mathrm{SH}$ groups determination. For this purpose, pellet $(200 \mu \mathrm{l})$ was solubilized by incubating $300 \mu \mathrm{L}$ of $20 \% \mathrm{v} / \mathrm{v}$ Sodium dodecyl sulphate (SDS) reagent in $3 \mathrm{ml}$ of $100 \mathrm{mM}$ sodium phosphate $(\mathrm{pH} 8.0)$, for $30 \mathrm{~min}$ at $37^{\circ} \mathrm{C}$. Samples were further incubated with $100 \mu \mathrm{l}$ of $10 \mathrm{mM}$ DTNB (5,5'-dithiobis-(2-nitrobenzoic acid) in $100 \mathrm{mM}$ sodium phosphate $(\mathrm{pH} 8.0)$, for $20 \mathrm{~min}$ at $37^{\circ} \mathrm{C}$. DTNB reacts specifically with thiol groups producing a highly colored yellow anion. Levels of membrane - $\mathrm{SH}$ groups were spectrophotometrically read at 405 $\mathrm{nm}^{21}$ and expressed as percentage of $-\mathrm{SH}$ groups in untreated erythrocytes.

\section{Determination of Malondialdehyde levels}

To assess oxidative stress, levels of MDA, as end product of lipid peroxidation, have been measured on both treated and untreated erythrocytes. ${ }^{26}$ The assay is based on the reaction between MDA and thiobarbituric acid (TBA) which produces thiobarbituric acid-reactant substances, colorimetrically detectable at $532 \mathrm{~nm}$ wavelength. Erythrocytes, after washing, were suspended to $3 \%$ hematocrit in isotonic medium and incubated with either $300 \mu \mathrm{M}$ or $1 \mathrm{mM} \mathrm{CdCl}_{2}$ plus $2 \mathrm{mM} \mathrm{NaF}$ for one hour at $37^{\circ} \mathrm{C}$. Samples were 
centrifuged (ThermoScientific, $1000 \mathrm{~g}, 5 \mathrm{~min}$ ), suspended to $10 \%$ hematocrit in $1 \mathrm{~mL}$ distilled water to induce hemolysis and frozen overnight at $-20^{\circ} \mathrm{C}$ until analysis. After thawing, sample aliquots $(200 \mu \mathrm{L})$ were treated with $500 \mu \mathrm{L}$ TBA $(1 \% \mathrm{v} / \mathrm{v}$ dissolved in $1 \mathrm{~N}$ $\mathrm{HCl}$ ) and incubated at $95^{\circ} \mathrm{C}$ for $1 \mathrm{~h}$. Samples were then cooled on ice, centrifuged $\left(13000 \mathrm{~g}, 15 \mathrm{~min}, 4^{\circ} \mathrm{C}\right)$ and the supernatant spectrophotometrically read at $532 \mathrm{~nm}$. MDA levels were converted in micromolar by comparing results with a calibration standard curve previously obtained by known concentrations of 1,1,3,3tetramethoxypropan 99\% MDA bis (dimethyl acetal) 99\% (Sigma).

\section{Erythrocytes membrane preparation and Sodium dode- cyl sulphate-PolyAcrylamide gel electrophoresis}

Membrane extracts were prepared as previously described ${ }^{9}$ with slight modifications. Briefly, after washing, packed erythrocytes were diluted into $1.5 \mathrm{~mL}$ of cold hemolysis buffer (2.5 mM Sodium Phosphate, $1 \mathrm{mM}$ EGTA, $\mathrm{pH}$ 8) containing a protease and phosphatase inhibitor cocktail (1 mM PMSF, $1 \mathrm{mM} \mathrm{NaF}, 1 \mathrm{mM}$ Sodium Orthovanadate) and then repeatedly centrifuged (Eppendorf, $13000 \mathrm{~g}, 4^{\circ} \mathrm{C}$ ) to discard hemoglobin. Membrane were then solubilized by $1 \%(\mathrm{v} / \mathrm{v})$ SDS and incubated on ice for $20 \mathrm{~min}$. Solubilized membrane proteins, contained in the supernatant, were addressed to protein content quantification, according to Bradford method ${ }^{27}$ and frozen at $-80^{\circ} \mathrm{C}$ until use. Membranes obtained from each experimental condition, once thawed, were solubilized in Laemmli Buffer ${ }^{28}$ in a volume ratio of $1: 1$, heated for 5 min at $95^{\circ} \mathrm{C}$ and then loaded ( $2 \mu \mathrm{g}$ proteins). Samples were then separated on $12 \%$ polyacrylamide gel under reducing conditions and then transferred to polyvinylidenefluoride (PVDF) membrane.

\section{Western blot analysis}

PVDF membranes were incubated at $4{ }^{\circ} \mathrm{C}$ overnight with monoclonal anti-Band 3 protein (1:100000; Santa Cruz Biotechnology, produced in mouse) diluted in $1 \times$ phosphate-buffered saline, $5 \%(\mathrm{w} / \mathrm{v})$ non-fat dried milk and $0.1 \%$ Tween-20. Membranes were then incubated with peroxidase-conjugated goat anti-mouse IgG secondary antibodies (1:5000, Affini Pure), for $1 \mathrm{~h}$ at room temperature, followed by chemioluminescent detection, according to the manufacturer's instruc-tions (Super Signal West Pico Chemiluminescent Substrate, Pierce Thermo Scientific, Rockford, IL,

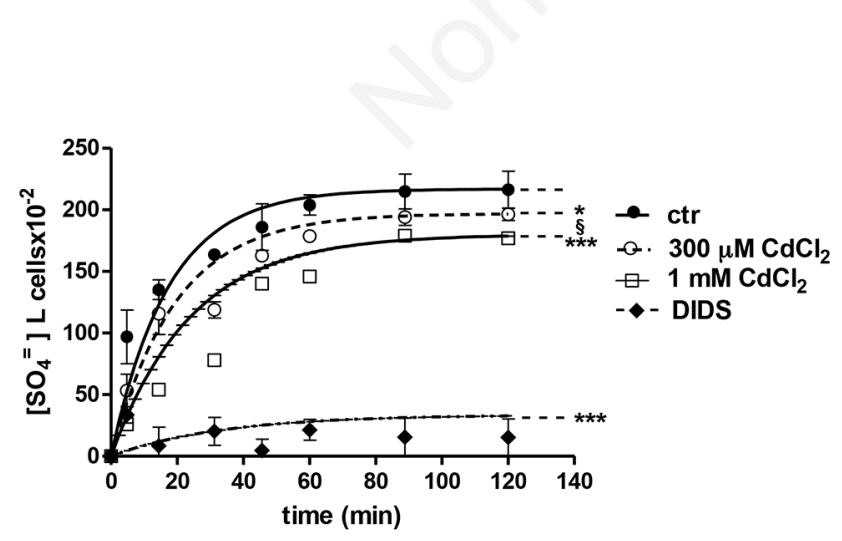

Figure 1. Time course of $\mathrm{SO}_{4}=$ uptake measured in control (untreated erythrocytes) or in erythrocytes treated with either $300 \mu \mathrm{M} \mathrm{Cd}^{2+}$, or $1 \mathrm{mM} \mathrm{Cd}^{2+}$ or $10 \mu \mathrm{M} 4,4$ '-diisothiocyanatostilbene-2, 2'-disulphonic acid (DIDS). ${ }^{*} \mathrm{P}<0.05$ and ${ }^{* * *} \mathrm{P}<0.001$ vs control, ${ }^{\$} \mathrm{P}<0.05$ vs $300 \mu \mathrm{MM}$ $\mathrm{Cd}^{2+}$, as determined by one-way analysis of variance followed by Bonferroni's Multiple Comparison post hoc test, by comparing all values of theoretical curves, at all time points $(\mathrm{N}=6)$.
USA). To verify whether blots contained equal amounts of protein, they were also incubated with monoclonal antibodies against $\beta$-actin (1:1000, Santa Cruz Biotechnology) produced in mouse. Quantification of Band 3 protein (approximately $95 \mathrm{kDa}$ ) expression was done by densitometry (Bio-Rad ChemiDoc ${ }^{\mathrm{TM}}$ XRS equipped with Image Quant 171 TL, v2003) and standardized to $\beta$-actin levels. Molecular weight standards, ranging between 10 and $250 \mathrm{kDa}$, were used to define molecular weight positions.

\section{Experimental data and statistics}

Data are expressed as means \pm S.E.M. GraphPad Prism software (version 5.00 for Windows; San Diego, CA) was used. Significant differences between means were tested by paired one-way analysis of variance (ANOVA), followed by Bonferroni's, post hoc test. Statistically significant differences were assumed at $\mathrm{P}<0.05$ $(* \mathrm{P}<0.05, * * \mathrm{P}<0.01, * * * \mathrm{P}<0.001) ; N$ represents the number of independent experiments.

\section{Results}

\section{$\mathrm{SO}_{4}=$ uptake measurement}

Treatment with $\mathrm{Cd}^{2+}$ at all concentrations did induce hemolytic events. With regard to $\mathrm{SO}_{4}{ }^{=}$uptake measurement, doses lower than $300 \mu \mathrm{M}$ did not significantly alter the rate constant, therefore data presented in Figure 1 refer to $\mathrm{SO}_{4}{ }^{=}$uptake in either $300 \mu \mathrm{M}$ or 1 $\mathrm{mM} \mathrm{Cd}{ }^{2+}$-treated erythrocytes, compared to control (untreated erythrocytes) and reported as a function of time. The velocity of this process is represented by the rate constant for $\mathrm{SO}_{4}{ }^{=}$uptake $\left(\mathrm{min}^{-1}\right)$.

$\mathrm{SO}_{4}=$ transport in control erythrocytes progressively increased and reached equilibrium in $30 \mathrm{~min}$, with a rate constant of $0.057 \pm 0.001 \mathrm{~min}^{-1}$ (time to reach $63 \%$ of total $\mathrm{SO}_{4}{ }^{*}$ intracellular total amount $=17 \mathrm{~min})$. Erythrocytes treated with $300 \mu \mathrm{M} \mathrm{Cd}^{2+}$ exhibited a rate constant of $0.051 \pm 0.001 \mathrm{~min}^{-1}$ (19 $\left.\mathrm{min}\right)$, significantly lower than those observed in control conditions $(\mathrm{P}<0.05)$ and total amount of $\mathrm{SO}_{4}{ }^{=}$internalized at $30 \mathrm{~min}$ and 45 min by such treated cells $(118.75 \pm 6.5 \mathrm{mM}$ and $162.72 \pm 4.3 \mathrm{mM}$ respectively, Table 1) was significantly lower those determined in control at both time intervals $(163.72 \pm 2.4 \mathrm{mM}$ and $186 \pm 18 \mathrm{mM}$ respectively, Table 1). Similarly, erythrocytes exposed to $1 \mathrm{mM} \mathrm{Cd}^{2+}$ showed a rate constant for $\mathrm{SO}_{4}=$ uptake $\left(0.041 \pm 0.001 \mathrm{~min}^{-1}, 24 \mathrm{~min}\right)$ significantly lower than control $(\mathrm{P}<0.001)$ and $\mathrm{SO}_{4}{ }^{=}$total amount trapped by the cells at $30 \mathrm{~min}$ and $45 \mathrm{~min}(78.52 \pm 11 \mathrm{mM}$ and $140 \pm 8.8 \mathrm{mM}$ respectively, Table 1) significantly lower than what determined in untreated erythrocytes at both time intervals (163.72 $\pm 2.4 \mathrm{mM}$ and $186 \pm 18 \mathrm{mM}$ respectively, Table 1).

Treatment with $10 \mu \mathrm{M}$ DIDS applied at the beginning of incubation in $\mathrm{SO}_{4}{ }^{=}$medium completely blocked $\mathrm{SO}_{4}{ }^{=}$uptake (rate constant of $0.018 \pm 0.001 \mathrm{~min}^{-1}, 55 \mathrm{~min}$ ) and significantly reduced $\mathrm{SO}_{4}{ }^{=}$total amount detected at both 30 and $45 \mathrm{~min}(20.25 \pm 12 \mathrm{mM}$ and $4.75 \pm 9 \mathrm{mM}$ respectively, Table 1) with respect to both control and $\mathrm{Cd}^{2+}$-treated cells $(\mathrm{P}<0.001)$.

As said, $\mathrm{Cd}^{2+}$ concentrations comprised between 50 and 200 $\mu \mathrm{M}$ did not alter the rate constant for $\mathrm{SO}_{4}=$ uptake when compared to the control, and, hence, have been not shown and no longer considered for the experimental protocol.

\section{Membrane-SH groups determination}

Determination of membrane - $\mathrm{SH}$ groups was performed in erythrocytes treated with either $300 \mu \mathrm{M}$ or $1 \mathrm{mM} \mathrm{Cd}^{2+}$ (Figure 2). After exposure to $300 \mu \mathrm{M} \mathrm{Cd}^{2+}$, levels of membrane $-\mathrm{SH}$ groups 
were not significantly different when compared to control (untreated erythrocytes), while, after treatment with $1 \mathrm{mM} \mathrm{Cd}^{2+}$, significantly lower than those of untreated erythrocytes $(\mathrm{P}<0.001)$. Results were compared to what obtained after treatment with $2 \mathrm{mM}$ NEM, a thiol oxidizing compound, which significantly reduced -SH groups when compared to control (Figure 2, $\mathrm{P}<0.001$ ).

\section{Malondialdehyde membrane levels}

As shown in Figure 3, levels of MDA, the end product of lipid peroxidation, in erythrocytes treated with either $300 \mu \mathrm{M}$ or $1 \mathrm{mM}$ $\mathrm{Cd}^{2+}$ were significantly higher than those measured in control conditions (untreated erythrocytes, $\mathrm{P}<0.001$ ). These data have been compared with MDA levels produced by the oxidant $\mathrm{NaF}$, known to induce a significant lipoperoxidation. As expected, in this latter case MDA levels were significantly higher than those measured in both control and $\mathrm{Cd}^{2+}$ treated $(300 \mu \mathrm{M}$ and $1 \mathrm{mM})$ erythrocytes $(\mathrm{P}<0.001)$.

\section{Western blot analysis}

Band 3 protein expression levels in erythrocytes treated with either $300 \mu \mathrm{M}$ or $1 \mathrm{mM} \mathrm{Cd}^{2+}$ were not significantly different with respect to those determined in untreated erythrocytes (Figure 4).

\section{Discussion}

In the present investigation experiments have been carried out to evaluate anion exchange capability through Band 3 protein after a brief exposure of human erythrocytes to $\mathrm{Cd}^{2+}$. For this purpose, the rate constant for $\mathrm{SO}_{4}{ }^{=}$uptake has been determined, as $\mathrm{SO}_{4}=$ can be more slowly exchanged than $\mathrm{Cl}^{-}$and, hence, more easily measured. ${ }^{2,23}$ This parameter accounts for one of Band 3 protein functions, which, as currently known, involves gas exchange, membrane deformability and ion balance across erythrocytes

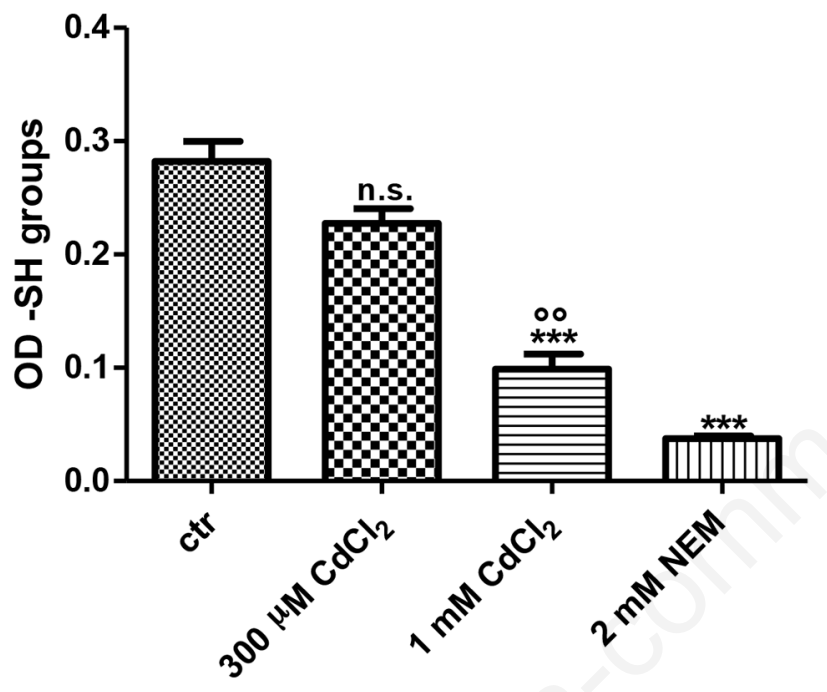

Figure 2. Membrane -SH groups levels (expressed as optical density, OD measured in control (untreated erythrocytes) or in either $300 \mu \mathrm{M}$ or $1 \mathrm{mM} \mathrm{Cd}^{2+}$ or $2 \mathrm{mM} \mathrm{N}$-Ethylmaleimide (NEM)treated erythrocytes. Bars represent the mean \pm SEM from at least 8 experiments, where n.s. not significant $v s$ control, ${ }^{* *} \mathrm{P}<0.001$ vs control, ${ }^{\circ} \mathrm{P}<0.01$ vs $300 \mu \mathrm{M} \mathrm{Cd}{ }^{2+},{ }^{\mathfrak{S} S} \mathrm{P}<0.001$ vs $300 \mu \mathrm{M} \mathrm{Cd}^{2+}$,

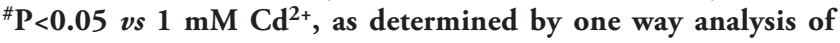
variance followed by Bonferroni's Multiple Comparison post hoc test.

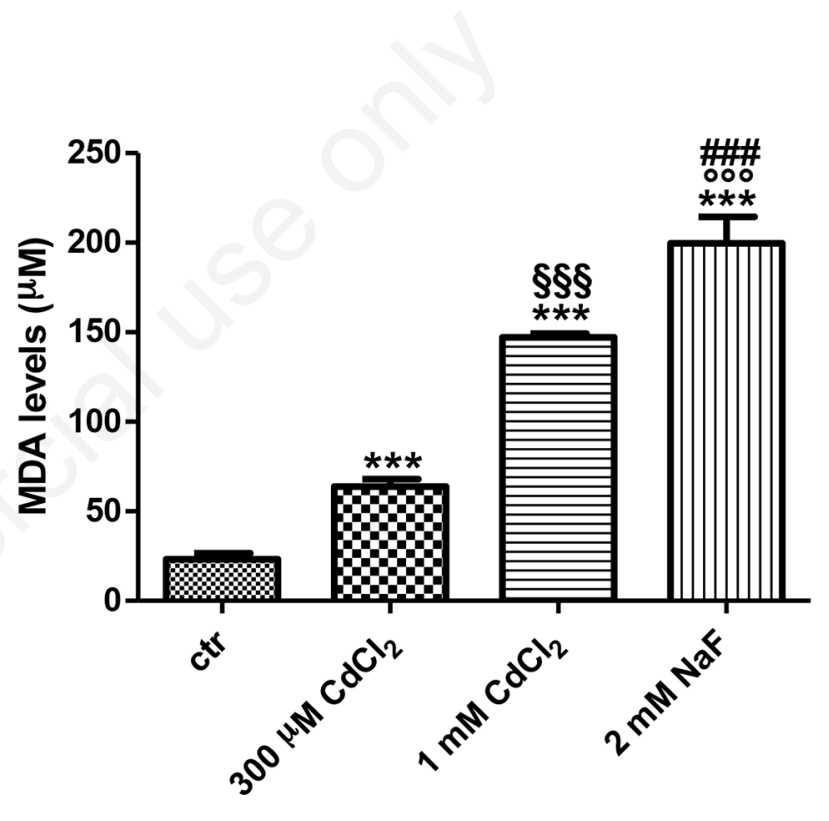

Figure 3. Malonyldialdehyde (MDA) levels (expressed as $\mu \mathrm{M}$ ) measured in control (untreated erythrocytes) and in erythrocytes treated with either $300 \mu \mathrm{M}$ or $1 \mathrm{mM} \mathrm{Cd}^{2+}$ or $2 \mathrm{mM} \mathrm{NaF}$. Bars represent the mean \pm SEM from at least 7 experiments, where

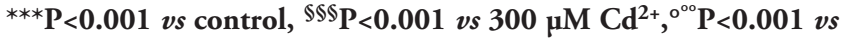
$300 \mu \mathrm{M} \mathrm{Cd}^{2+},{ }^{\# \#} \mathrm{P}<0.001$ vs $1 \mathrm{mM} \mathrm{Cd}^{2+}$ as determined by one way analysis of variance followed by Bonferroni's Multiple Comparison post hoc test.

Table 1. Amount of $\mathrm{SO}_{4}=$ trapped in human erythrocytes during $\mathrm{SO}_{4}=$ kinetics experiments and measured at both 30 and 45 min (at equilibrium) in control conditions (untreated erythrocytes) or in erythrocytes treated with either $\mathrm{CdCl}_{2}$ at different concentrations (300 $\mu \mathrm{M}$ and $1 \mathrm{mM}$ ) or $10 \mu \mathrm{M} 4,4^{\prime}$-diisothiocyanatostilbene-2, 2'-disulphonic acid (DIDS). Data are presented as means \pm SEM from separate $N$ experiments, where: ${ }^{* * *} \mathrm{P}<0.001$ and ${ }^{* *} \mathrm{P}<0.01$ vs control; ${ }^{\circledR} \mathrm{P}<0.05$ vs $300 \mu \mathrm{M} \mathrm{CdCl} 2$ as determined by one-way analysis of variance followed by Bonferroni's Multiple Comparison post hoc test.

\begin{tabular}{|c|c|c|c|c|c|}
\hline Time (min) & Control & $\begin{array}{l}\mathrm{mM} \mathrm{SO}_{4}=\text { trap } \\
300 \mathrm{\mu M} \mathrm{CdCl}_{2}\end{array}$ & $\begin{array}{l}\text { rythrocytes } \\
1 \mathrm{mM} \mathrm{CdCl}\end{array}$ & $10 \mu \mathrm{M}$ DIDS & $\mathbf{N}$ \\
\hline $30 \mathrm{~min}$ & $163.72 \pm 2.4$ & $118.75 \pm 6.5^{* *}$ & $78.52 \pm 11^{* * *}, \S$ & $20.25 \pm 12^{* * *}$ & 4 \\
\hline $45 \mathrm{~min}$ & $186.00 \pm 18$ & $162.72 \pm 4.3^{* *}$ & $140.00 \pm 8.8^{* * *}, \S$ & $4.75 \pm 9 * * *$ & 4 \\
\hline
\end{tabular}


membrane. ${ }^{2,23}$ The efficiency of Band 3 protein in anion exchange not only depends on an intact protein structure, but also on its crosslink with other proteins, including cytoskeletal components, hemoglobin and Glucose-6-phosphate dehydrogenase, placed underneath erythrocytes membrane. ${ }^{29}$ Hence, alterations at level of Band 3 protein may impact on these components, and vice versa.

In the recent years, monitoring of Band 3 protein anion exchange capability has been more widely used to assay the effect of different conditions, i.e. toxins and oxidants ${ }^{6,22,30-32}$ or of diseases. ${ }^{5,6}$ In this context, as previous investigations revealed that the rate constant for $\mathrm{SO}_{4}=$ uptake is a sensitive tool to detect the effects of xenobiotics, ${ }^{22}$ this parameter has been used in the present work to verify the effect of $\mathrm{Cd}^{2+}$ on erythrocytes homeostasis, in an attempt to provide a novel tool for diagnosis and monitoring of development of cadmium $\mathrm{Cd}^{2+}$ toxicity-related pathologies. This issue is in line with what recently proven by Morabito et al., reporting about Band 3 protein monitoring in diseases associated to oxidative stress, such as canine leishmaniasis ${ }^{33}$ and Systemic sclerosis. ${ }^{5}$

The present results show that the rate constant for $\mathrm{SO}_{4}=$ uptake is significantly reduced by a transient exposure to both $300 \mu \mathrm{M}$ and $1 \mathrm{mM} \mathrm{Cd}^{2+}$, putatively mediated by a significant increase in MDA levels in both experimental conditions and a decrease in membrane $-\mathrm{SH}$ groups only in $1 \mathrm{mM} \mathrm{Cd}^{2+}$-treated erythrocytes. Interestingly, the metal seems not to alter the expression levels of Band 3 protein.

At his point, we may suggest that the reduction in anion exchange capability is affected by $\mathrm{Cd}^{2+}$ via different mechanisms depending on $\mathrm{Cd}^{2+}$ concentration, as the oxidative state of membrane-SH groups is not affected by low-concentrated $\mathrm{Cd}^{2+}$. Hence, an impairment of Band 3 protein function in this experimental condition may be more likely due to a lipoperoxidative effect of $\mathrm{Cd}^{2+}$, as attested by high MDA levels, rather than on a direct oxidation of membrane-SH groups. Though this result is in line with what already described by Tezcan et al., ${ }^{18}$ reporting about
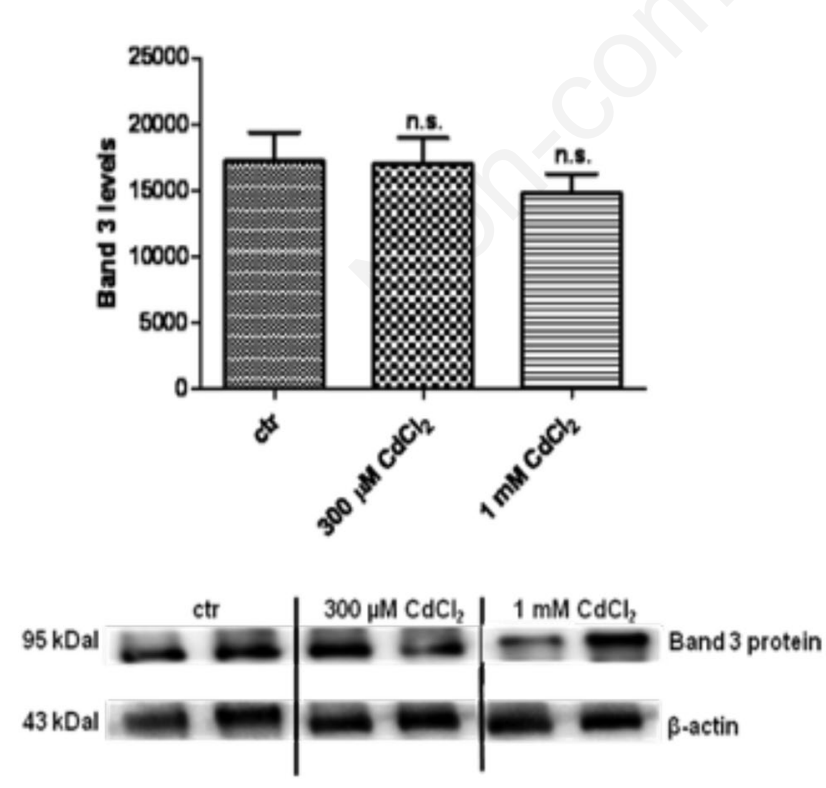

Figure 4. Band 3 protein and $\beta$-actin expression levels in control (untreated erythrocytes) and in erythrocytes treated with either 300

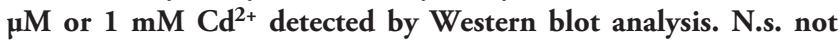
significant $v s$ control as determined by one-way analysis of variance followed by Bonferroni's Multiple Comparison post hoc test $(\mathrm{N}=4)$.
MDA production in human erythrocytes after 1 hour $\mathrm{Cd}^{2+}$ treatment, its novelty relies in the altered anion exchange capability through Band 3 protein, never proven so far.

The evidence that oxidation state of membrane - $\mathrm{SH}$ groups is critically involved in the efficiency of transport through Band 3 protein is actually supported by other studies, as - $\mathrm{SH}$ groups mostly belong to Band 3 protein structure. ${ }^{21}$ The importance of changes in Band 3 protein structure caused by cysteine $-\mathrm{SH}$ groups oxidation, especially after exposure to NEM and $\mathrm{pH} 6.5$, has been already proven. ${ }^{34}$ Nevertheless, the correspondence between reduced membrane - $\mathrm{SH}$ groups and Band 3 protein anion exchange capability may be not always univocal, as Morabito et al., ${ }^{30}$ have demonstrated that $\mathrm{H}_{2} \mathrm{O}_{2}$, used as an oxidant molecule on human erythrocytes, significantly reduced the rate constant for $\mathrm{SO}_{4}=$ uptake through Band 3 protein, but did not alter $-\mathrm{SH}$ groups levels. At this point, we could even suggest that $300 \mu \mathrm{M} \mathrm{Cd}^{2+}$ may act on Band 3 protein with a mechanism similar to that one exerted by $\mathrm{H}_{2} \mathrm{O}_{2}{ }^{30}$ with the difference that, based on the present findings, $\mathrm{Cd}^{2+}$ affects Band 3 protein via lipid peroxidation, while $\mathrm{H}_{2} \mathrm{O}_{2}$, not inducing lipid peroxidation, seems to inflict damage by putatively affecting cytoplasmic components, cross linking with Band 3 protein. ${ }^{30}$

As said, a second result from the present study, confirming what already reported by other authors, ${ }^{18,35}$ is that $\mathrm{Cd}^{2+}$ induces oxidative stress by increasing lipid peroxidation. MDA is a marker of membrane lipid peroxidation resulting from the interaction of ROS and cell membrane, which may be attributed to alterations in the antioxidant defense system, including glutathione (GSH) peroxidase, superoxide dismutase, catalase as well as non-enzymatic antioxidants, such as reduced glutathione. ${ }^{19,36}$ In particular, cadmium $\mathrm{Cd}^{2+}$ has high affinity for cell membrane, probably deriving from its strong interaction with lipids. ${ }^{37}$ Both $300 \mu \mathrm{M}$ and $1 \mathrm{mM} \mathrm{Cd}^{2+} \mathrm{CdCl} 2$, which did not induce hemolysis, induced lipid peroxidation on erythrocytes membrane, with consequent impairment of anion exchange capability through Band 3 protein. A cell membrane re-arrangement due to $\mathrm{Cd}^{2+}$-induced lipid peroxidation, in line with what previously observed by Suwalsky et al. ${ }^{14}$ seems to be responsible for the reduction in rate constant for $\mathrm{SO}_{4}=$ uptake observed after exposure to $300 \mu \mathrm{M} \mathrm{Cd}^{2+}$. Noteworthy, the hypothesis that $\mathrm{Cd}^{2+}$-induced lipoperoxidation may contribute to the membrane-SH groups decrease observed after treatment with $1 \mathrm{mM} \mathrm{Cd}^{2+} \mathrm{CdCl} 2$ can't be excluded at all. In this regard, other authors also showed that oxidative events from alcohol administration clearly induced erythrocytes lipid peroxidation increase, $-\mathrm{SH}$ groups decrease and deplation of antioxidant enzyme activities. ${ }^{38}$ On this basis lipid peroxidation would affect not only the arrangement of membrane bilayer, which per se is sufficient to reduce the rate constant of $\mathrm{SO}_{4}=$ uptake, ${ }^{5,33}$ but also the oxidation state of membrane - $\mathrm{SH}$ groups, essential for Band 3 protein function. Such combined effect would finally result in a reduction in anion exchange capability.

To better focus on the effect of $\mathrm{Cd}^{2+}$, expression levels of Band 3 protein in treated erythrocytes have been evaluated. As the decrease in the rate constant for $\mathrm{SO}_{4}=$ uptake observed in $\mathrm{Cd}^{2+}$-treated erythrocytes is not associated to reduced Band 3 protein expression levels, the inhibitory effect would be rather due to the oxidation state of Band 3 protein -SH groups, or lipoperoxoidative events when high concentrated $\mathrm{Cd}^{2+}$ is considered. Therefore, these findings corroborate the hypothesis that the rate constant for $\mathrm{SO}_{4}{ }^{=}$uptake is a sensible tool to evaluate erythrocytes homeostasis under oxidative conditions, namely when changes in parameters currently associated to oxidative stress are undetectable. Moreover, Band 3 protein transport efficiency may be useful to assay the effects of heavy metals, whose impact on public health represents a common threat. 
One more finding arising from the present work is related to $\mathrm{Cd}^{2+}$ concentrations. In particular, to prove a possible effect of $\mathrm{Cd}^{2+}$ on Band 3 protein, a brief exposure to the metal, according to what reported in other in vitro tests ${ }^{14}$ has been used. As pointed out by Suwalsky et al., ${ }^{14} \mathrm{Cd}^{2+}$ was applied at concentrations up to 10 folds higher than those either used in in vivo experiments or reported as tolerable weekly intake in humans, when $\mathrm{Cd}^{2+}$ enters food chain. ${ }^{18}$ Nonetheless, they are not hemolytic and allow to rapidly evaluate erythrocytes function and morphology after a brief exposure to the metal.

As $\mathrm{Cd}^{2+}$ concentrations lower than $300 \mu \mathrm{M}$ are proven not to alter the rate constant for $\mathrm{SO}_{4}=$ uptake (data not shown), they could be proposed as not observed effect levels, though an in vivo investigation is required to better prove this aspect.

Among heavy metals, cadmium $\mathrm{Cd}^{2+}$ displays a variety of effects $^{35,39,40}$ and molecular mechanisms have been tentatively explained, though not completely unraveled. The evidence that membrane transport systems, along with antioxidants enzymes activity and GSH levels are affected in in vivo models by exposure to $\mathrm{Cd}^{2+}$ has been already proven, ${ }^{13}$ but such effects have been described after chronic $\mathrm{Cd}^{2+}$ administration, which implies that detoxification systems and time to reach the Minimum Effective Dose should be taken into account. In this context, the present investigation would add some more knowledge about the impact of this metal on cell membrane and ion transport systems. Morabito and co-workers ${ }^{41}$ have already demonstrated that HEK 293 Phoenix cells, exposed to $200 \mu \mathrm{M} \mathrm{Cd}^{2+}$ are not able to exhibit a homeostatic response to hyposmotic shock, referred to as Regulatory Volume Decrease, common to many cell types and mediated by both ion transport through channels and exchangers. ${ }^{42}$ The evidence that ion transport can be targeted by $\mathrm{Cd}^{2+}$ motivated the present choice of verifying the efficiency of a specific ion exchanger, such as Band 3 protein, in an anucleated cell, based also on Tezcan et al., ${ }^{18}$ hypothesis for explaining $\mathrm{Cd}^{2+}$ mechanism of action. These authors point out that a direct interaction of $\mathrm{Cd}^{2+}$ with ion transport systems may explain $\mathrm{Cd}^{2+}$ toxicity, though an inter-action between the metal and membrane phospholipids affecting ion channel activity can't be excluded at all. On this basis, $\mathrm{Cd}^{2+}$ toxicity is not specific at the membrane level.

Erythrocytes have been reasonably chosen as a model for this type of investigation, being continuously threatened by oxidative events, namely related to aging, strenuous exercise, and pathologies associated to high ROS levels. ${ }^{43,44}$ Therefore, their possible adaptation to oxidative stress, and in particular to $\mathrm{Cd}^{2+}$-induced oxidative stress, could add more information to both toxicology and oxidative stress impact on cells.

\section{Conclusions}

Taken together these findings show that: i) a significant reduction in the rate constant for $\mathrm{SO}_{4}=$ uptake through Band 3 protein is seen after exposure to $\mathrm{Cd}^{2+}$; ii) such reduction is mainly due to lipid peroxidation at low $\mathrm{Cd}^{2+}$ concentrations, while, at higher concentrations, to a possible combined effect lipid peroxidation acting on lipid bilayer arrangement and on membrane-SH groups oxidation as well; iii) in both cases expression levels of Band 3 protein are not altered; iv) Band 3 protein anion exchange capability is a suitable tool to monitor toxic effects of $\mathrm{Cd}^{2+}$. Further studies are needed to better focus on signaling pathways possibly involved in alterations of Band 3 protein function with possible use of antioxidants preventing detrimental $\mathrm{Cd}^{2+}$ effects.

\section{References}

1. Steck TL. The organization of proteins in the human red blood cell membrane. J Cell Biol 1974;62:1-19.

2. Arakawa T, Kobayashi-Yurugi T, Alguel Y, et al. Crystal structure of the anion exchanger domain of human available online erythrocyte band 3. Science 2015;350:680-4.

3. Tomishige M, Sako Y, Kusumi A. Regulation mechanism of the lateral diffusion of band 3 in erythrocyte membranes by the membrane skeleton. J Cell Biol 1998;42:989-1000.

4. Kodippili GC, Spector J, Kang GE, et al. Analysis of the kinetics of band 3 diffusion in human erythroblasts during assembly of the erythrocyte membrane skeleton. $\mathrm{Br} \mathrm{J}$ Haematol 2010;150:592-600.

5. Morabito R, Remigante A, Bagnato G, et al. Band 3 protein function and oxidative stress in erythrocytes from systemic sclerosis patients with interstitial lung disease. EJCBS 2017;34:80-4.

6. Teti D, Crupi M, Busà M, et al. Chemical and pathological oxidative influences on band 3 protein anion-exchanger. Cell Physiol Biochem 2005; 16:77-86.

7. Anong WA, Franco T, Chu H, et al. Adducin forms a bridge between the erythrocyte membrane and its cytoskeleton and regulates membrane cohesion. Blood 2009;114:1904-12.

8. Snyder LM, Fortier NL, Trainor J, et al. Effect of hydrogen peroxide exposure on normal human erythrocyte deformability, morphology, surface characteristics, and spectrin-hemoglobin cross-linking. J Clin Invest 1985;76:1971-7.

9. Pantaleo A, Ferru E, Pau MC, et al. Band 3 erythrocyte membrane protein acts as redox stress sensor leading to its phosphorylation by p 72 Syk. Ox Med Cell Long 2016;21:1-11.

10. Ikediobi CO, Badisa VL, Ayuk-Takem LT, et al. Response of antioxidant enzymes and redox metabolites to cadmiuminduced oxidative stress in CRL-1439 normal rat liver cells. Int J Mol Med 2004;14:87-92.

11. Habeebu SS, Liu J, Klaassen CD. Cadmium-apoptosis in mouse liver. Toxicol Appl Pharmacol 1998;149:203-9.

12. Bauman JW, Liu J, Klaassen CD. Production of metallothionein and heat-shock proteins in response to metals. Fundam Appl Toxicol 1993;21:15-22.

13. Sarkar S, Yadav P, Bhatnagar D. $\mathrm{Cd}^{2+}$ induced lipid peroxidation and the antioxidant system in rat erythrocytes: Role of antioxidants. J Trace Elem Biol 1997;11:8-13.

14. Suwalsky M, Villena F, Norris B, et al. Cadmium-induced changes in the membrane of human erythrocytes and molecular models. J Inorg Biochem 2004;98:1061-6.

15. Satarug JR, Baker S, Haswell-Elkins PEB, et al. A global perspective on cadmium pollution and toxicity in nonoccupationally exposed population. Toxicol Lett 2003;137:65-83.

16. Chaney RL, Ryan JA, Li YM, Brown SL. Soil cadmium as a threat to human health. In: McLaughlin MJ, Singh BR, eds. Developments in plant and soil sciences, 85. Dordrecht: Kluwer Academic Publishers; 1999. pp 219-256.

17. Steffensen IL, Mesna OJ, Andruchow E, et al. Cytotoxicity and accumulation of $\mathrm{Hg}, \mathrm{Ag}, \mathrm{Cd}, \mathrm{Cu}, \mathrm{Pb}$ and $\mathrm{Zn}$ in human peripheral $\mathrm{T}$ and $\mathrm{B}$ lymphocytes and monocytes in vitro. Gen Pharmacol 1994;25:1621-33.

18. Tezcan Ö, Pandir D, Ba H. The effects of cadmium on enzymatic antioxidant system and lipid peroxidation of human erythrocytes in vitro and the protective role of plasma level of vitamins C and E. Pol J Environ Stud 2012;21:1849-54.

19. Girault L, Boudou A, Dufourc EJ. 113 Cd-, 31P-NMR and 
fluorescence polarization studies of cadmium(II) interactions with phospholipids in model membranes. Biochim Biophys Acta 1998;1414:140-54.

20. Asar M, Kayisly UA, Izgut-Uysal VN, et al. Cadmium-induced changes in parietal cell structure and functions of rats. Biol Trace El Res 2000;74:153-70.

21. Roy SS, Sen G, Biswas T. Role of sulfhydryl groups in band 3 in the inhibition of phosphate transport across erythrocyte membrane in visceral leishmaniasis. Arch Biochem Biophys 2005;436:121-7.

22. Morabito R, Marino A, Romano P, et al. Sulphate and chloridedependent potassium transport in human erythrocytes are affected by crude venom from nematocysts of the jellyfish Pelagia noctiluca. Cell Physiol Biochem 2013;32:86-95.

23. Romano L, Passow H. Characterization of anion transport system in trout red blood cell. Am J Physiol 1984;246:330-8.

24. Jennings ML. Proton fluxes associated with erythrocyte membrane anion exchange. J Membrane Biol 1976;28:187-205.

25. Jessen F, Sjoholm C, Hoffmann EK. Identification of the anion exchange protein of Ehrlich cells: a kinetic analysis of the inhibitory effects of 4,4'-diisothiocyano-2,2'-stilbene-disulfonic acid (DIDS) and labeling of membrane proteins with 3H-DIDS. J Membrane Biol 1986;92:195-205.

26. Jain SK, Levine SN, Duett J, Hollier B. Elevated lipid peroxidation levels in red blood cells of streptozotocin-treated diabetic rats. Metabolism 1990;39:971-5.

27. Bradford MM. A rapid and sensitive method for the quantitation of microgram quantities of protein utilizing the principle of protein-dye binding. Anal Biochem 1976;72:248-54.

28. Laemmli UK. Cleavage of structural proteins during the assembly of the head of bacteriophage T4. Nature 1970;5259:680-5.

29. Pantaleo A, Ferru E, Giribaldi G, et al. Oxidized and poorly glycosylated band 3 is selective lyphosphorylated by Syk kinase to form large membrane clusters in normal and G6PD-deficient red blood cell. Biochem J 2009;418:359-67.

30. Morabito R, Romano O, La Spada G, Marino A. $\mathrm{H}_{2} \mathrm{O}_{2}$-induced oxidative stress affects $\mathrm{SO}_{4}=$ transport in human erythrocytes. PlosOne 2016;11:1-16.

31. Morabito R, Remigante A, Casili G, et al. Magnesium prevents both $\mathrm{H}_{2} \mathrm{O}_{2}$-and NEM-induced oxidative damage at Band 3 protein level in human erythrocytes. Proceedings of the $68^{\text {th }}$ SIF National Congress, Italian Physiological Society, 2017 Sept 68, Pavia, Italy; 2017. pp 149.
32. Morabito R, Remigante A, Di Pietro ML, et al. $\mathrm{SO}_{4}{ }^{=}$uptake and catalase role in preconditioning after $\mathrm{H}_{2} \mathrm{O}_{2}$-induced oxidative stress in human erythrocytes. Pflugers Arch 2017;469:235-50.

33. Morabito R, Remigante A, Cavallaro M, et al. Anion exchange through band 3 protein in canine leishmaniasis at different stages of disease. Pflugers Arch 2017;469:713-24.

34. Morabito R, Falliti G, Geraci A, et al. Curcumin protects -SH groups and sulphate transport after oxidative damage in human erythrocytes. Cell Physiol Biochem 2015;36:345-57.

35. Manca D, Ricard AC, Trottier B, Chevalier G. In vitro and in vivo responses of rat tissues to cadmium-induced lipid peroxidation. Bull Environ Contam Toxicol 1991;46:929-36.

36. Cimen MY. Free radical metabolism in human erythrocytes. Clin Chim Acta 2007;390:1-11.

37. El-Demerdash FM, Yousef MI, Kedwany FS, Baghdadi HH. Cadmium-induced changes in lipid peroxidation, blood hematology, biochemical parameters and semen quality of male rats: protective role of vitamin $\mathrm{E}$ and $\mathrm{b}$-carotene. Food Chem Toxicol 2004;42:1563-71.

38. Jabri MA, Sani M, Ritibi K, et al, Chamomile decoction extract inhibits human neutrophils ROS production and attenuates alchol-induced haematological parameters changes and erythrocytes oxidative stress in rat. Lipid Health Dis 2016;15:65.

39. Hussein T, Shukla GS, Chandra SV. Effects of cadmium on superoxide dismutase and lipid peroxidation in liver and kidney of growing rats: In vivo and in vitro studies. Basic Clin Pharmacol Toxicol 1987;60:355-8.

40. Calderoni AM, Oliveros L, Jahn G, et al. Alterations in the lipid content of pituitary gland and serum prolactin and growth hormone in cadmium treated rats. Biometals 2005; 18:213-20.

41. Morabito R, Remigante A, Costa R, et al. $\mathrm{Cd}^{2+}$ affects regulatory volume decrease (RVD) in cultured human kidney (HEK 293 Phoenix) cells. J Biol Res 2016;89:12-9.

42. Hoffmann EK, Sørensen BH, Sauter DP, et al. Role of volumeregulated and calcium-activated anion channels in cell volume homeostasis, cancer and drug resistance. Channels (Austin) 2015;9:380-96.

43. Macchi B, Di Paola R, Marino-Merlo F, et al. Inflammatory and cell death pathways in brain and peripheral blood in Parkinson's disease. CNS Neurol Disord Drug Targets 2015;14:313-24.

44. Inal ME, Kanbak G, Sunal E. Antioxidant enzyme activities and malondialdehyde levels related to aging. Clin Chim Acta 2001;305:75-80. 